\title{
PRENYLLIPIDS AND PIGMENTS CONTENT IN SELECTED ANTARCTIC LICHENS AND MOSSES
}

\author{
KAZIMIERZ STRZALKA $a^{*}$, RENATA SZYMANSKA, MARIO SUWALSKY $Y^{b^{*}}$ \\ ${ }^{a}$ Department of Plant Physiology and Biochemistry, Faculty of Biochemistry, Biophysics and Biotechnology, Jagiellonian University, \\ Gronostajowa 7, 30-387 Krakow, Poland. \\ ${ }^{b}$ Faculty of Chemical Sciences, University of Concepción, Concepción, Chile \\ (Received: March 28, 2011 - Accepted: July 25, 2011)
}

\begin{abstract}
The content and relative composition of tocopherols, plastochromanol, plastoquinone and pigments in fifteen Antarctic species (five mosses and ten lichens) were analyzed by HPLC. Total tocopherols in mosses ranged from $90 \mu \mathrm{g} / \mathrm{g}$ (Warnstrofia sarmentosa) to $220 \mu \mathrm{g} / \mathrm{g}$ (Syntrichia magellanica), while in lichens it ranged from $0.89 \mu \mathrm{g} / \mathrm{g}$ in Caloplaca sp. to $45 \mu \mathrm{g} / \mathrm{g}$ in Placopsis contortuplicata. With the exception of Ochrolechia frigida, in all other mosses and lichens species, $\alpha$-tocopherol accounted for more than $90 \%$ of total tocopherols. Plastochromanol was detected in four mosses and two lichen species; the highest level was found in Polytrichastrum alpinum $(19.1 \mu \mathrm{g} / \mathrm{g})$. The highest content of plastoquinone-9 (PQ-9) in mosses was found in Bryum pseudotriquetrum (42.6 $\mu \mathrm{g} / \mathrm{g})$, whereas in lichens it was $24.5 \mu \mathrm{g} / \mathrm{g}$ in Stereocaulon alpinum, and $23.17 \mu \mathrm{g} / \mathrm{g}$ in Umbilicaria antarctica. Pigment composition in mosses was typical for higher plants. Some lichen species lacked chlorophyll $b$, violaxanthin and $\beta$-carotene. Based on these results it is suggested that tocochromanols and carotenoid pigments are involved in the protection of mosses and lichens against the oxidative stress caused by the extreme Antarctic conditions.
\end{abstract}

Keywords: Antarctica; lichens; mosses; pigments; tocopherols; plastochromanol; plastoquinone

\section{INTRODUCTION}

Antarctic, on average, is the coldest, driest and windiest continent, and it has the highest average elevation of all continents. Antarctic is considered a desert, with annual precipitation of only $200 \mathrm{~mm}$ along the coast and far less inland. Only cold-adapted plants and animals can survive there. Plants growth is inhibited by low temperatures, poor soil quality, prolonged drought, high solar irradiance, ultraviolet-B radiation levels, and winter darkness ${ }^{1}$. Flora largely consists of lichens, bryophytes, algae, and fungi, which generally occur in summer. Nowadays more than 200 species of lichens and 50 species of bryophytes are known to exist and only two species of flowering plants can be found: Deschampsia antarctica and Colobanthus quitensis ${ }^{2}$. Extreme Antarctic conditions increase the reactive oxygen species (ROS) formation. Thus plants and lichens contain considerable amounts of antioxidants to protect them against damage caused by oxidation in its extreme environmental conditions ${ }^{3}$.

Tocochromanols are a group of four $(\alpha, \beta, \mathrm{g}, \delta)$ lipophilic antioxidants synthesized by all photosynthetic organisms, occurring mainly in leaves and seeds ${ }^{4}$. Tocochromanols contain a polar chromanol "head" and isoprenoid side chain ("tail") antioxidant activity ${ }^{7,8}$. The only difference between them is a longer prenyl chain in the structure of PC-8 (eight isoprenoid subunits) (Fig. 1). Plastochromanol has been found in vegetable oils'; its richest source is Brassica napus, Linum sp. oil, and Cannabis sativa seeds $7,10,11$, and widespread in leaves ${ }^{8,12,13}$. Tocochromanols are antioxidants that participate in the inhibition of membrane lipid peroxidation, scavenging ROS and free radicals ${ }^{5,14}$. They are also involved in plant metabolism participating in sugar export from leaves to phloem ${ }^{15,16}$.

\begin{tabular}{|c|c|c|}
\hline $\begin{array}{c}\text { Tocopherol/ } \\
\text { Tocotrienol }\end{array}$ & $\mathrm{R}_{1}$ & $\mathbf{R}_{2}$ \\
\hline$\alpha$ & $\mathrm{CH}_{3}$ & $\mathrm{CH}_{3}$ \\
\hline$\beta$ & $\mathrm{CH}_{3}$ & $\mathbf{H}$ \\
\hline$\gamma$ & $\mathbf{H}$ & $\mathrm{CH}_{3}$ \\
\hline$\delta$ & $\mathrm{H}$ & $\mathbf{H}$ \\
\hline
\end{tabular}
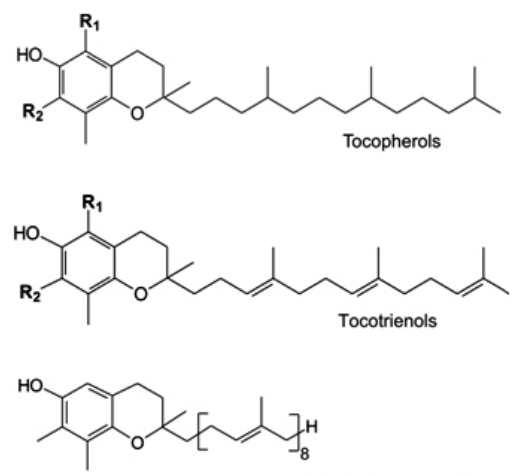

Plastochromanol-8

Figure 1. Chemical structure of tocochromanols.
Because of the nutritional importance of vitamin E, literature data on content and composition of tocopherols have mainly been focused on seed oils, where its reported concentration reaches up to $2 \mathrm{mg} / \mathrm{g}$ oil ${ }^{17}$; in leaves it is usually significantly lower $(10-50 \mu \mathrm{g} / \mathrm{g}$ fresh weight), between $300-500 \mathrm{mg} / \mathrm{g}$ fresh weight in oil palm ${ }^{18}$ and a few tropical plants ${ }^{19}$, and nearly $1 \mathrm{mg} / \mathrm{g}$ fresh weight in Eucalyptus gunni $i^{20}$. Concerning the composition of tocopherol homologues, $\gamma$-tocopherol prevails in seed oils, while $\alpha$-tocopherol is the predominant form in leaves $(>90 \%)^{21,22}$. Interestingly, tocopherol pattern is present in lettuce ${ }^{17}$, ${ }^{22}$, young leaves of runner bean ${ }^{23}$ and parasitic dodder shoots ${ }^{22,}{ }^{24}$ where $\gamma$ - or $\delta$-tocopherol occur in the highest amounts. Significance of these differences is so far unknown.

Plastoquinone (PQ) is mainly known as a component of the electron transport chain in photosynthesis, but its reduced form $\left(\mathrm{PQH}_{2}\right)$ shows, similarly to tocopherols, antioxidant activity in vitro ${ }^{8,25,26}$. It has also been shown that $\mathrm{PQH}_{2}$ may inhibit in vivo ${ }^{27}$ membrane lipid peroxidation, and scavenge reactive oxygen species ${ }^{28,29}$. Numerous data also indicate the regulatory function of the PQ-pool in many physiological and molecular processes ${ }^{30}$.

Photosynthetic organisms have developed a number of strategies to avoid damage caused by oxidative stress. One of them is the xantophyll cycle (violaxanthin cycle) in which the reversible conversion of violaxanthin to zeaxanthin via antheraxanthin occurs ${ }^{31,32}$. The xantophyll cycle is essential for the adaptation of all vascular plants and many algae to different light conditions.

As part of our current interest on Antarctic flora, we now report the results of a study on the prenyllipids (tocochromanols and plastoquinone) and pigments of five moss and ten lichen species growing in King George and Ardley islands. By HPLC analysis of the extracts, the relative concentrations of $\alpha$-tocopherol, $\gamma$-tocopherol, $\delta$-tocopherol, plastochromanol, oxidized and reduced forms of plastoquinone (PQ) and photosynthetic pigments were obtained.

\section{EXPERIMENTAL}

Five moss species (Syntrichia magellanica, Polytrichastrum alpinum, Sanionia georgicouncinata, Warnstrofia sarmentosa, Bryum pseudotriquetrum) and ten lichen species (Turgidosculum complicatulum, Sphareophorus globorus, Placopsis contortuplicata, Caloplaca regalis, Ochronlechne frigide, Usnea aurantiaco-atra, Stereocaulon alpinum, Caloplaca coralloides, Himantornia lugubris, Ochrolechia frigida, Umbilicaria antarctica) were collected from natural standings in the Ardley and King George Antarctic islands during the southern hemisphere summer. Mosses were identified by Professor Ryszard Ochyra from Wladyslaw Szafer Institute of Botany, Polish Academy of Sciences (Krakow, Poland), and the lichen species by Professor Maria Olech from Institute of Botany, Jagiellonian University (Krakow, Poland).

In order to perform tocopherols and pigments analysis, a sample 150-300 $\mathrm{mg}$ of mosses and lichens material was frozen in liquid nitrogen, crushed by 
baguette and ground in a mortar with $2 \mu \mathrm{l}$ of cold HPLC solvent (acetonitrile/ methanol/water, $72 / 8 / 1, \mathrm{v} / \mathrm{v} / \mathrm{v})$. The extract was transferred to an Eppendorf tube and shaked on vortex for 3 hours. After that, the extract was centrifuged (10 min) on a benchtop centrifuge (10 $000 \mathrm{~g})$ and analyzed by HPLC (100 $\mathrm{mL}$, triplicate). For plastochromanol (PC) and plastoquinone (PQ) analysis the same method was applied but with a different HPLC solvent (methanol/ hexane, 340/20, v/v). The HPLC measurements were performed in a 100 $\mathrm{mL}$ loop, Jasco PU-980 pump and a UV-VIS UV-970 detector system (255 $\mathrm{nm}$ for PQ and $\mathrm{PC}$ detection and $440 \mathrm{~nm}$ for pigments detection), Shimadzu RF10-AXL fluorescence detector (excitation/emission detection at 290/330 $\mathrm{nm}$ ), Teknokroma (Barcelona, Spain), $\mathrm{C}_{18}$ reverse-phase column (Nucleosil $100,250 \times 4 \mathrm{~mm}, 5 \mathrm{~mm})$ and isocratic solvent system - acetonitrile/methanol/ water $(72 / 8 / 1, \mathrm{v} / \mathrm{v} / \mathrm{v})$ or methanol/hexane $(340 / 20 ; \mathrm{v} / \mathrm{v})$ at the flow rate of 1.5 $\mathrm{mL} / \mathrm{min}$. PQ-9 and its reduced form was obtained and prepared as described by Kruk ${ }^{33}$. Tocopherol homologues of HPLC grade ( $\geq 99.5 \%$ ) (Merck), PQ-9 was obtained as previously described ${ }^{33}$, and PC was dotained according to the procedure described by Gruszka and Kruk ${ }^{11}$.

Pigments were measured by HPLC using $100 \mu \mathrm{L}$ loop, Agilent Technologies Series 1200 (Waldbronn, Germany) Quat Pump and DAD detector (440 nm), Tecnocroma (Barcelona, Spain) $C_{18}$ reverse-phase column and isoctaric solvent system acetonitrile/water $(78 / 8 / 1, \mathrm{v} / \mathrm{v} / \mathrm{v})$ at flow rate $1.5 \mathrm{~mL} / \mathrm{min}$.

\section{RESULTS AND DISCUSSION}

Table 1 presents the content of $\alpha$-, $\gamma$ - and d-tocopherol, plastochromanol and plastoquinone (both oxidized and reduced) content of the five different Antarctic moss species.

Table 1. Tocopherols, plastochromanol and plastoquinone content of selected Antarctic mosses. $N=3 \pm$ SE. ( $\alpha$-T, $\alpha$-tocopherol; $\gamma$-Toc, $\gamma$-tocopherol; $\delta$-Toc, $\delta$-tocopherol; Toc, tocopherols; PC, plastochromanol; DW, dry weight).

\begin{tabular}{|l|c|c|c|c|c|c|}
\hline Species & $\begin{array}{c}\delta \text {-Toc } \\
{[\mu \mathrm{g} / \mathrm{g} \mathrm{DW}]}\end{array}$ & $\begin{array}{c}\gamma-\mathrm{Toc} \\
{[\mu \mathrm{g} / \mathrm{g} \mathrm{DW}]}\end{array}$ & $\begin{array}{c}\alpha-\mathrm{Toc} \\
{[\mu \mathrm{g} / \mathrm{g} \mathrm{DW}]}\end{array}$ & $\begin{array}{c}\mathrm{PC} \\
{[\mu \mathrm{g} / \mathrm{g} \mathrm{DW}]}\end{array}$ & $\begin{array}{c}\mathrm{PQH}_{2} \\
{[\mu \mathrm{g} / \mathrm{g} \mathrm{DW}]}\end{array}$ & $\begin{array}{c}\mathrm{PQ} \\
{[\mu \mathrm{g} / \mathrm{g} \mathrm{DW}]}\end{array}$ \\
\hline Syntrichia magellanica & 0.0 & $3.2 \pm 0.65$ & $217.0 \pm 28$ & $3.6 \pm 1.0$ & $18.2 \pm 2.30$ & $4.8 \pm 0.90$ \\
\hline Polytrichastrum alpinum & 0.0 & $2.2 \pm 0.60$ & $199.6 \pm 12$ & $19.1 \pm 0.85$ & 0.0 & $16.2 \pm 1.30$ \\
\hline Sanionia georgicouncinata & $1.2 \pm 0.1$ & $6.4 \pm 0.55$ & $212.2 \pm 6.5$ & 0.0 & $10.7 \pm 1.70$ & $18.1 \pm 2.40$ \\
\hline Warnstrofia sarmentosa & 0.0 & $1.2 \pm 0.05$ & $88.4 \pm 5.8$ & $3.8 \pm 0.8$ & 0.0 & $9.5 \pm 1.40$ \\
\hline Bryum pseudotriquetrum & 0.0 & $4.2 \pm 0.56$ & $157.4 \pm 16$ & $12.7 \pm 2.20$ & $26.7 \pm 2.80$ & $15.9 \pm 1.80$ \\
\hline
\end{tabular}

Content of $\alpha$-tocopherol ranged between $88.4 \mu \mathrm{g} / \mathrm{g}$ in Warnstrofia sarmentosa and $217 \mu \mathrm{g} / \mathrm{g}$ in Syntrichia magellanica. In all examined species the content of $\alpha$-homologue was fairly high in comparison to higher plants. The typical content of tocopherols in mature leaves of higher plant is in the range of $30-50 \mu \mathrm{g} / \mathrm{g}^{17,22}$. Thus, in the case of examined mosses the amount of tocopherols was about 4-fold higher. Such high levels of tocopherols have been reported for autumn tree leaves ${ }^{22}$, Patagonian plants ${ }^{12}$ and a few tropical plants ${ }^{19}$. The increased level of these compounds is connected with stress circumstances. In the case of Antarctic mosses oxidative stress is caused by low temperature, lack or excess of sunlight and lack of accessible water. It has been reported that chilling and drought stress enhance superoxide production ${ }^{34}$. Asada ${ }^{35}$ showed that superoxide dismutase, which is responsible for scavenging of superoxide is inactivated by low temperature. In such situations, tocopherols might take over the role of dismutase. It was also established that $\alpha$-tocopherol is engaged in chilling stress response, while $\gamma$-tocopherol plays a role in drought stress ${ }^{23}$. $\gamma$-Tocopherol was present in all analyzed species, being its content relatively low (between 1.2 and $6.4 \mu \mathrm{g} / \mathrm{g}$ ). $\delta$-Tocopherol was present only in Sanionia georgicouncinata $(1.2 \mu \mathrm{g} / \mathrm{g})$. With the exception of Sanionia georgicouncinata, the remaining species contain plastochromanol, a homologue of $\gamma$-tocotrienol. The highest content of plastochromanol was found in Polytrichastrum alpinum $(19.1 \mu \mathrm{g} / \mathrm{g})$ and Bryum pseudotriquetrum $(12.7 \mu \mathrm{g} / \mathrm{g})$. PC has antioxidant properties $^{7}$, and its occurrence in the Antarctic mosses might be connected with ROS protection. Plastoquinone (oxidized) content varied between 4.8 and $18.1 \mu \mathrm{g} / \mathrm{g}$. The plastoquinol $\left(\mathrm{PQH}_{2}\right)$ content was higher than $\mathrm{PQ}$, but $\mathrm{PQH}_{2}$ was not present in Polytrichastrum alpinum, and Warnstrofia sarmentosa. The total value of PQ was the highest in Bryum pseudotriquetrum $(42.6 \mu \mathrm{g} / \mathrm{g})$ and the lowest in Warnstrofia sarmentosa $(9.5 \mu \mathrm{g} / \mathrm{g})($ Table 1). PQ-9 levels were not as high as previously reported for Patagonian plants ${ }^{12}$. The selected mosses are shown in Figure 2.

Lichens, a dominant life form throughout Antarctic are a good source of natural bioactive compounds which are related to their adaptability to extreme conditions. Table 2 presents the relative concentrations of $\gamma$-tocopherol, $\alpha$-tocopherol, plastochromanol and oxidized and reduced PQ found in ten selected Antarctic lichen species. In all species $\alpha$-tocopherol was present, with the highest content in Placopsis contortuplicata $(40.4 \mu \mathrm{g} / \mathrm{g})$ and Turgidosculum complicatulum $(34.65 \mu \mathrm{g} / \mathrm{g}$ ) (Table 2).
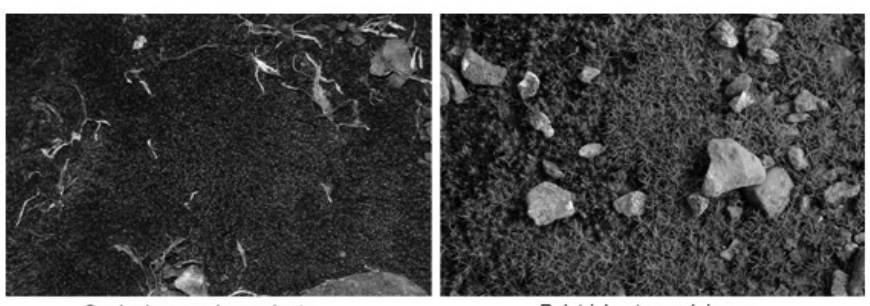

Sanionia georgicouncinata

Polytrichastrum alpinum
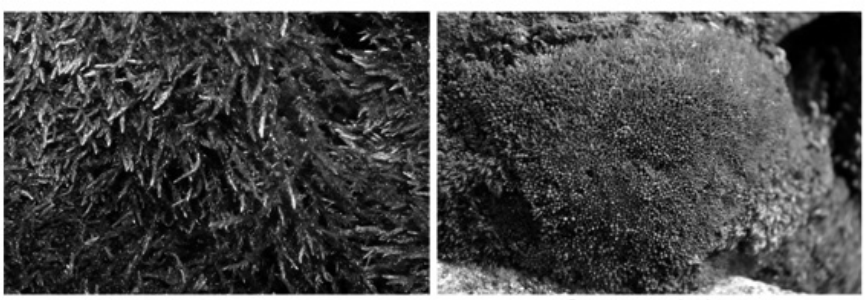

Warnstrofia sarmentosa

Bryum pseudotriquetrum

Figure 2. Selected mosses from King George Island (Antarctica).

Caloplaca sp. and Himantornia lugubris had the lowest $\alpha$-tocopherol content. $\gamma$-Tocopherol was present in three species (Sphareophorus globorus, Placopsis contortuplicata and Ochrolechia frigida). $\delta$-Tocopherol was not detected in any of the lichens analyzed. Plastochromanol was present in Placopsis contortuplicata and Usnea aurantiaco-atra, but its content was very low ( 0.6 and $0.98 \mu \mathrm{g} / \mathrm{g}$, respectively) (Table 2$)$. The total plastoquinone content was the highest in Stereocaulon alpinum, Himantornia lugubris and Umbilicaria antarctica. In Sphareophorus globorus and Himantornia lugubris plastoquinone occurred only in a reduced state, whereas in Placopsis contortuplicata, Caloplaca regalis, Caloplaca sp. only in the oxidized state; the remaining analyzed species had both PQ forms (Table 2). 
Table 2. Tocopherols, plastochromanol and plastoquinone content of selected Antarctic lichens. $N=3 \pm$ SE. ( $\alpha$-T, $\alpha$-tocopherol; $\gamma$-T, $\gamma$-tocopherol; Tocs, tocopherols; PC, plastochromanol; DW, dry weight).

\begin{tabular}{|l|c|c|c|c|c|}
\hline Species & $\begin{array}{c}\gamma-\mathrm{Toc} \\
{[\mu \mathrm{g} / \mathrm{g} \mathrm{DW}]}\end{array}$ & $\begin{array}{c}\alpha-\mathrm{Toc} \\
{[\mu \mathrm{g} / \mathrm{g} \mathrm{DW}]}\end{array}$ & $\begin{array}{c}\mathrm{PC} \\
{[\mu \mathrm{g} / \mathrm{g} \mathrm{DW}]}\end{array}$ & $\begin{array}{c}\mathrm{PQH}_{2} \\
{[\mu \mathrm{g} / \mathrm{g} \mathrm{DW}]}\end{array}$ & $\begin{array}{c}\mathrm{PQ} \\
{[\mu \mathrm{g} / \mathrm{g} \text { DW }]}\end{array}$ \\
\hline Turgidosculum complicatulum & 0.0 & $34.65 \pm 0.67$ & 0.0 & $13.26 \pm 1.2$ & $4.22 \pm 0.1$ \\
\hline Sphareophorus globorus & $0.33 \pm 0.05$ & $1.9 \pm 0.3$ & 0.0 & $4.03 \pm 0.8$ & 0.0 \\
\hline Placopsis contortuplicata & $5.15 \pm 0.67$ & $40.4 \pm 4.82$ & $0.6 \pm 0.004$ & 0.0 & $1.2 \pm 0.25$ \\
\hline Caloplaca regalis & 0.0 & $5.44 \pm 6.1$ & 0.0 & 0.0 & $8.06 \pm 2.1$ \\
\hline Stereocaulon alpinum & 0.0 & $7.86 \pm 2.1$ & 0.0 & $8.74 \pm 0.9$ & $15.75 \pm 1.1$ \\
\hline Caloplaca sp. & 0.0 & $0.89 \pm 0.03$ & 0.0 & 0.0 & $2.34 \pm 0.8$ \\
\hline Usnea aurantiaco-atra & 0.0 & $2.19 \pm 0.8$ & $0.98 \pm 0.04$ & $12.02 \pm 3.2$ & $0.76 \pm 0.56$ \\
\hline Himantornia lugubris & 0.0 & $0.93 \pm 0.06$ & 0.0 & $24 \pm 2.9$ & 0.0 \\
\hline Ochrolechia frigida & $21.12 \pm 3.7$ & $19.6 \pm 3.3$ & 0.0 & 7.25 & $2.15 \pm 0.07$ \\
\hline Umbilicaria antarctica & 0.0 & $3.96 \pm 1.0$ & 0.0 & $21.27 \pm 4.7$ & $1.9 \pm 0.6$ \\
\hline
\end{tabular}

The presence of tocopherols, $\mathrm{PC}$ and $\mathrm{PQH}_{2}$ in selected Antarctic lichens might be connected with its antioxidant functions. Bhattarai at $\mathrm{al}^{36}$ showed that methanol-water extracts of few Antarctic lichen species exhibited strong antioxidant action. The highest level of antioxidants was present in Stereocaulon alpinum from King George Island, while the stronger antioxidant activity was found in the extracts of Streocaulon alpinum, Caloplaca regalis and Caloplaca sp. ${ }^{36}$. On the other hand, Luo et $\mathrm{at}^{37}$ showed that acetone extracts from Antarctic lichen species had higher antioxidant properties than methanol extracts. Caloplaca regalis contains bioactive compounds, which have immunomodulatory effect on the macrophages in vitro ${ }^{38}$. Umbilicaria antarctica was found to be the lichen species with potent antioxidative capacity $^{37}$. Furthermore, Paudel et a ${ }^{39}$ showed that extracts from Antarctic lichens have strong antibacterial potential against human pathogenic bacteria. Our data confirm these reports and indicate that tocochromanols and $\mathrm{PQH}_{2}$ from lichen extracts are involved in antioxidant action. Antarctic lichens and their bioactive compounds can be used as novel biosources of natural antioxidants. In traditional medicine some lichen species has been widely used for treating many diseases. Many literature data report that bioactive substances from Antarctic species show inhibitory effect on cell proliferation ${ }^{40}$, antibacterial properties $^{41}$, antiviral, antifungal and anti-inflammatory effects ${ }^{42}$. Figure 3 show the Antarctic lichens with the highest tocochromanol content.

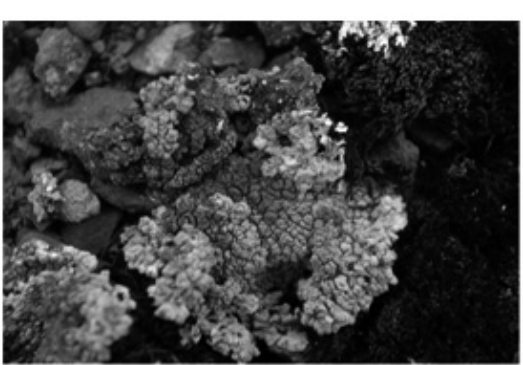

PLACOPSIS CONTORTUPLICATA

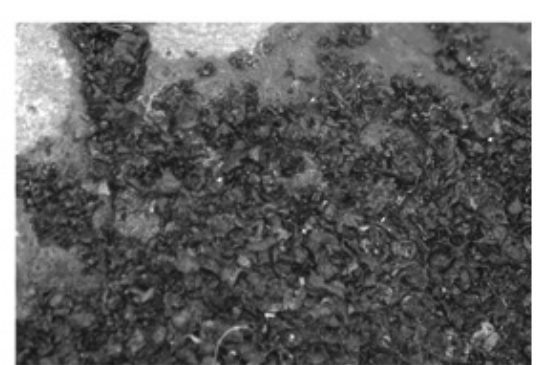

TURGIDOSCULUM COMPLICATUM

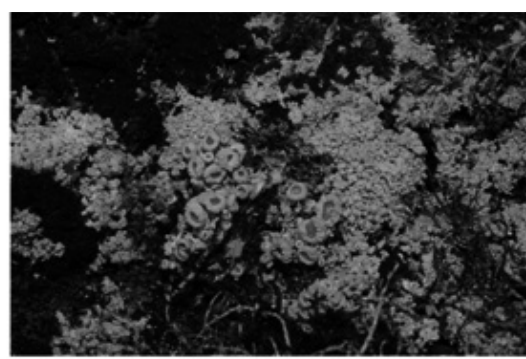

OCHROLECHIA FRIGIDA

Figure 3. Lichen species with the highest tocochromanols content.

Table 3. Percentage content of photosynthetic pigments in selected Antarctic mosses. $N=3 \pm$ SE; (Neo, Neoxanthin; Viol, Violaxanthin; EpL, Lutein Epoxide; Ant, Anteraxanthin; Lut, Lutein; Zea, Zeaxanthin; Chl a, Chlorophyll a; Chl b, Chlorophyll b; Car, b-Carotene)

\begin{tabular}{|l|c|c|c|c|c|c|c|c|c|}
\hline \multirow{2}{*}{\multicolumn{1}{|c|}{ Species }} & \multicolumn{7}{|c|}{ Pigments [\%] } \\
\cline { 2 - 10 } & Neo & Viol & EpL & Ant & Lut & Zea & Chl $b$ & Chl $a$ & Car \\
\hline $\begin{array}{l}\text { Syntrichia } \\
\text { magellanica }\end{array}$ & $8.4 \pm 1.0$ & $8.9 \pm 0.04$ & 0.0 & $1.0 \pm 0.01$ & $20.06 \pm 2.1$ & $0.57 \pm 0.003$ & $20.08 \pm 3.7$ & $37.05 \pm 5.9$ & $3.83 \pm 0.07$ \\
\hline $\begin{array}{l}\text { Polytrichastrum } \\
\text { alpinum }\end{array}$ & $6.73 \pm 1.4$ & $10.7 \pm 0.6$ & 0.0 & $0.76 \pm 0.02$ & $22.33 \pm 4.9$ & $0.32 \pm 0.01$ & $18.36 \pm 3.3$ & $37.24 \pm 7.5$ & $3.56 \pm 0.5$ \\
\hline $\begin{array}{l}\text { Sanionia } \\
\text { georgicouncinata }\end{array}$ & $7.58 \pm 1.1$ & $11.36 \pm 2.2$ & $0.03 \pm 0.002$ & $0.4 \pm 0.001$ & $22.14 \pm 2.7$ & $0.73 \pm 0.01$ & $19.88 \pm 2.1$ & $33.28 \pm 4.8$ & $4.6 \pm 0.86$ \\
\hline $\begin{array}{l}\text { Warnstrofia } \\
\text { armentosa }\end{array}$ & $7.78 \pm 1.0$ & $8.17 \pm 2.2$ & $0.09 \pm 0.005$ & $0.25 \pm 0.004$ & $22.8 \pm 1.7$ & $0.38 \pm 0.003$ & $20.5 \pm 4.2$ & $35.0 \pm 5.7$ & $5.02 \pm 0.95$ \\
\hline $\begin{array}{l}\text { Bryum } \\
\text { pseudotriquetrum }\end{array}$ & $7.25 \pm 2.4$ & $9.2 \pm 3.8$ & $0.25 \pm 0.09$ & $0.53 \pm 0.078$ & $22.65 \pm 4.9$ & $0.7 \pm 0.03$ & $17.74 \pm 3.7$ & $36.53 \pm 7.8$ & $5.15 \pm 1.6$ \\
\hline
\end{tabular}

The percentage content of photosynthetic pigments in analyzed mosses was typical for higher plants (Table 3). Chlorophyll a, b and lutein were the predominant pigments in all examined moss species. Lutein epoxide, which is typical for shaded leaves ${ }^{43}$ was found in three species: Sanionia georgicouncinata, Warnstrofia sarmentosa and Bryum pseudotriquetrum. Chlorophyll $a$, lutein, neoxanthin, zeaxanthin and antheraxanthin were found in all lichens (Table 4). 
Table 4. Percentage content of photosynthetic pigments in selected Antarctic lichens. $N=3 \pm$ SE. (Neo, Neoxanthin; Viol, Violaxanthin; EpL, Lutein Epoxide; Ant, Anteraxanthin; Lut, Lutein; Zea, Zeaxanthin; Chl a, Chlorophyll a; Chl b, Chlorophyll b; Car, b-Carotene).

\begin{tabular}{|l|l|l|l|l|l|l|l|l|}
\hline \multirow{2}{*}{ Species } & \multicolumn{1}{c|}{ Pigments [\%] } \\
\cline { 2 - 8 } & \multicolumn{1}{|c|}{ Neo } & \multicolumn{1}{c|}{ Viol } & \multicolumn{1}{c|}{ Ant } & \multicolumn{1}{c|}{ Lut } & \multicolumn{1}{c|}{ Zea } & \multicolumn{1}{c|}{ Chl $\beta$} & \multicolumn{1}{c|}{ Chl $\alpha$} & \multicolumn{1}{c|}{ Car } \\
\hline Turgidosculum complicatulum & $16.24 \pm 2.3$ & $7.47 \pm 0.57$ & $2.17 \pm 0.06$ & $18.76 \pm 2.2$ & $2.82 \pm 0.7$ & $15.52 \pm 2.4$ & $33.66 \pm 9.7$ & $3.36 \pm 0.8$ \\
\hline Sphareophorus globorus & $16.11 \pm 1.7$ & - & $23.94 \pm 5.9$ & $46.24 \pm 11$ & $5.14 \pm 0.87$ & - & $8.57 \pm 1.1$ \\
\hline Placopsis contortuplicata & $7.51 \pm 1.5$ & $4.32 \pm 0.97$ & $3.5 \pm 0.65$ & $34.15 \pm 7.1$ & $6.08 \pm 0.24$ & $9.22 \pm 1.5$ & $28.1 \pm 5.2$ & $7.12 \pm 1.1$ \\
\hline Caloplaca regalis & $15.34 \pm 1.2$ & $14.77 \pm 0.9$ & $4.5 \pm 0.34$ & $39.4 \pm 3.6$ & $1.18 \pm 0.08$ & $5.41 \pm 0.78$ & $17.36 \pm 2.1$ & $2.04 \pm 0.2$ \\
\hline Stereocaulon alpinum & $23.34 \pm 2.5$ & - & $7.06 \pm 0.86$ & $50.05 \pm 7.3$ & $12.45 \pm 1.8$ & - & $7.10 \pm 0.7$ & - \\
\hline Caloplaca sp & $14.73 \pm 3.4$ & $12.95 \pm 2.7$ & $5.15 \pm 0.52$ & $37.84 \pm 6.6$ & $1.44 \pm 0.08$ & $7.53 \pm 1.0$ & $19.35 \pm 3.2$ & $1.01 \pm 0.06$ \\
\hline Usnea aurantiaco-atra & $20.2 \pm 4.8$ & - & $24.7 \pm 3.9$ & 41.174 .4 & $8.53 \pm 0.67$ & - & $5.40 \pm 1.2$ & - \\
\hline Himantornia lugubris & $20.38 \pm 5.8$ & - & $12.03 \pm 2.9$ & $46.08 \pm 9.3$ & $6.54 \pm 0.56$ & - & $12.74 \pm 1.8$ & $2.23 \pm 0.05$ \\
\hline Ochrolechia frigida & $21.8 \pm 5.7$ & - & $10.93 \pm 2.8$ & $56.57 \pm 9.1$ & $2.52 \pm 0.03$ & $5.72 \pm 0.9$ & $2.46 \pm 0.04$ & - \\
\hline Umbilicaria antarctica & $20.87 \pm 2.8$ & - & $16.9 \pm 1.5$ & $45.2 \pm 7.2$ & $12.63 \pm 1.2$ & - & & $4.3 \pm 1.8$ \\
\hline
\end{tabular}

Apart of pigments, which play a crucial role in photosynthetic electron flow, zeaxanthin and lutein are known to have strong antioxidant properties ${ }^{44,45}$. Another protective mechanism is based on the acidification of thylakoid lumen and the activation of enzyme violxanthin de-epoxidase, which catalyzes violaxanthin conversion to zeaxanthin via antheraxanthin ${ }^{31,32}$. The xanthophyll cycle pigments were present in all moss species (Table 3).

In the case of lichens only four analyzed species (Turgidosculum complicatulum, Placopsis contortuplicata, Caloplaca regalis, Caloplaca sp.) contained the xantophyll cycle pigments (Table 4). The remaining lichens had no violaxanthin. Furthermore, in most species lack of violaxanthin was connected with the lack of $\beta$-carotene and chlorophyll $b$ (Table 4 ). Interestingly, lichens where violaxanthin was not present had high level of antheraxanthin (Table 4). This result might suggest that antheraxanthin compensates the lack of violaxanthin in protecting these species against oxidative stress.

In conclusion, this first report on lipophilic antioxidants in selected Antarctic moss and lichen species shows, as expected, significant variations in relative composition among genera. However, the observed enhancement of $\alpha$-tocopherol concentration in mosses and the high levels of the pigments lutein and neoxanthin detected in lichens, could be associated to adaptation to oxidative stress predominating in the site of collection. Further studies would be necessary in order to corroborate this matter.

\section{ACKNOWLEDGEMENTS}

This project was supported by FONDECYT (Project 1090041) and INACH (Project F_02-08). The research was carried out with the equipment purchased thanks to financial support of the European Regional Development Fund in the framework of the Polish Innovation Economy Operational Program (contract No. POIG.02.01.00-12-167/08, Project Małopolska Centre of Biotechnology).

Abbreviations: Ant, anteraxanthin; Car, beta-carotene; Chl, chlorophyll; DW, dry weight; Epl, lutein epoxides; Lut, lutein; Neo, neoxanthin, plastochromanol; PQ, plastoquinone; $\mathrm{PQH} 2$, reduced plastoquinone; TOC, tocopherols; Viol, violaxanthin; Zea, zeaxanthin.

\section{REFERENCES}

1. D.O. Øvstedal, R.I. Lewis Smith, Lichens of Antarctica and South Georgia. Cambridge University Press, Cambridge (2001).

2. D. Lud, A.H.L. Huiskes, T.C.W. Moerdijk, J Rozema, 2001. Plant Ecol. $154,89,(2001)$.

3. Z.E. Wilson, M.A. Brimble, Nat. Prod. Rep. 26, 44, (2008).

4. P. Dormann, Planta. 225, 269, (2007).

5. S. Munné-Bosch, L. Alegre, Crit. Rev. Plant Sci. 21, 31, (2002).

6. R. Kumar, M. Raclaru, T. Schüßeler, J Gruber, R. Sadre, W. Lühs, K.M. Zarhloul, W. Frierdt, D. Enders, M. Frentzen, D. Weier, FEBS Lett. 579, 1357, (2005).

7. D. Olejnik, M. Gogolewski, M. Nogala-Kałucka, Nahrung. 41, 101, (1997).

8. R. Szymanska, J. Kruk, Plant Cell Physiol. 51, 537, (2010).

9. M.K. Ahmed, J.K. Daun, R. Przybylski, J. Food Compos. Anal. 18, 359, (2005).

10. A.S.H. Ong, Natural sources of tocotrienols, L. Packer, J. Fuchs, Eds. Vitamin E in health and disease. New York L Dekker, (1993).

11. J. Gruszka, J. Kruk, Chromatographia. 66, 909, (2007).

12. K. Strzalka, R. Szymanska, E. Swiezewska, K. Skorupinksa-Tudek, M. Suwalsky, Acta Biol. Cracov. Bot. 51, 39, (2009).
13. A.M. Zbierzak, M. Kanwischer, C. Wille, P.A. Vidi, P. Giavalisco, A. Lohmann, I. Briesen, S. Porfirova, C. Brehelin, F. Kessler, P. Dörmann, Biochem. J. 425, 389, (2010).

14. L. Mène-Saffrané, D. DellaPenna, Plant Physiol. Biochem. 48, 301, (2010).

15. S. Porfirova, E. Bergmüller, S. Tropf, R. Lemke, P. Dörmann, PNAS 99, 12495, (2002).

16. D. Hofius, M.R. Hajirezaei, M. Geiger, H. Tschiersch, M. Melzer, U. Sonnewald, Plant Physiol. 135, 1256, (2004).

17. D. DellaPenna, J. Plant Physiol. 162, 729, (2005).

18. M. Grusak, D. DellaPenna, Annu. Rev. Plant Phys. 50, 133, (1999).

19. L.S. Ching, S. Mohamed, J. Agr. Food Chem. 49, 3101, (2001).

20. W. El Kayal, G. Keller, C. Debayles, R. Kumar, D. Weier, C. Teulieres, C. Marque, Physiol. Plantarum.126, 212, (2006).

21. H.K. Lichtenthaler, Photosynth. Res. 92, 163, (2007).

22. R. Szymanska, J. Kruk, Plant Physiol. Biochem. 46, 29, (2008a).

23. R. Szymanska, J. Kruk, Phytochemistry. 69, 2142, (2008b).

24. T.A.W. van der Kooij, K. Krupinska, K. Krause, J. Plant Physiol. 162, 777, (2005).

25. J. Kruk, G.H. Schmid, K. Strzalka,. Free Rad. Res. 21, 409, (1994).

26. J. Kruk, K. Burda, A. Raduni, K. Strzalka, G.H. Schmid, Z. Naturforsch. 52c, 203, (1997).

27. U. Maciejewska, L. Polkowska-Kowalczyk, E. Swiezewska, A. Szkopinksa, Acta Biochim. Pol. 49, 775, (2002).

28. J. Kruk, M. Jemiola-Rzeminska, K. Strzalka, Biochem. J. 375, 215, (2003).

29. J. Kruk, A. Trebst, Biochim. Biophys. Acta. 1777, 154, (2008).

30. S. Karpinski, H. Reynolds, B. Karpinska, G. Wingsle, G. Creissen, P.M. Mullineaux, Science. 284, 654, (1999).

31. D. Latowski, J. Grzyb, K. Strzalka, Acta Physiol. Plant. 26, 197, (2004).

32. P. Jahns, D. Latowski, K. Strzalka, Biochim. Biophys. Acta. 1787, 3 , (2009).

33. J. Kruk, Biophys. Chem. 30, 143, (1988)

34. M. Smirnoff, New Phytol. 125, 27, (1993).

35. K. Asada, Philos. T. R. Soc. B 355, 1419, (2000).

36. H.D. Bhattarai, B. Paudel, S.G. Hong, H.K. Lee, J.H. Yim, J. Nat. Med. $62,481,(2008)$.

37. H. Luo, Y. Yamamoto, J.A. Kim, J.S. Jung, Y.J. Koh, J-S. Hur, Polar Biol. 32, 1033, (2009).

38. H-S. Choi, J.H. Yim, H.K. Lee, S. Pyo, Mar. Biotechnol. 11, 90, (2009).

39. B. Paudel, H.D. Bhattarai, J.S. Lee, S.G. Hong, H.W. Shin, J.H. Yim, Phytother. Res. 22, 1269, (2008).

40. F. Bucar, I. Schneider, H. Ögmundsdóttir, K. Ingólfsdóttir, Phytomedicine. $11,602,(2004)$.

41. K. Ingólfssóttir, G.A.C. Chung, V.G. Skulason, S.R. Gissurarson, M. Vilhelmsdóttir, Pharm. Sci. 6, 141, (1998).

42. I. Oksanen, Appl. Microbiol. Biot. 73, 723, (2006).

43. J.I. Garcia-Plazaola, S. Matsubara, C.B. Osmond, Funct. Plant Biol. 34, $759,(2009)$.

44. M. Havaux, F. Eymery, S. Porfirova, P. Rey, P. Dörmann, Plant Cell. 17, 3451, (2005).

45. H. Vráblíková, M. Braták, A. Wonisch, J. Photoch. Photobio. B. 79, 35, (2005). 